\title{
Structure, magnetic properties and epoxidation activity of iron(III) salicylaldimine complexes
}

\author{
Huey-Lih Shyu, ${ }^{a}$ Ho-Hsiang Wei, ${ }^{* b}$ Gene-Hsaing Lee ${ }^{c}$ and Yu Wang ${ }^{c}$ \\ ${ }^{a}$ Chung-Tai Institute of Health Science and Technology, Taiwan \\ ${ }^{b}$ Department of Chemistry, Tamkang University, Tamsui, Taiwan. \\ E-mail: tkwei@mail.tku.edu.tw \\ ${ }^{c}$ Instrumentation Center of College of Science, National Taiwan University, Taipei, Taiwan
}

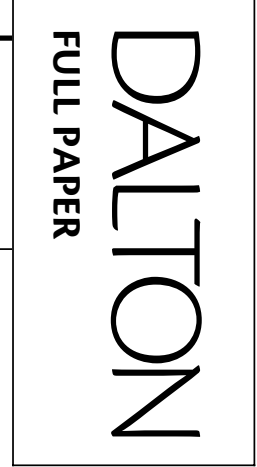

Received 1st November 1999, Accepted 25th January 2000

\begin{abstract}
Two new iron(III) complexes with salicylaldimine ligands, $\left[\mathrm{Fe}\left(\mathrm{L}^{1}\right) \mathrm{Cl}\right] \cdot \mathrm{CH}_{3} \mathrm{CN}(\mathbf{1})$ and $\left.\left[\mathrm{Fe}\left(\mathrm{L}^{2}\right) \mathrm{Cl}_{(\mathrm{H}} \mathrm{O}\right)\right] \cdot 1 / 3 \mathrm{CH}_{3} \mathrm{Cl}(\mathbf{2})$ $\left[\mathrm{H}_{2} \mathrm{~L}^{1}=N, N^{\prime}\right.$-(1,1-dimethylethylene)bis(salicylaldimine), $\mathrm{H}_{2} \mathrm{~L}^{2}=N, N^{\prime}$-(1,1-dimethylethylene)bis(3-methoxysalicylaldimine)], have been prepared and characterized. The X-ray crystal structure analysis shows that the iron(III) ion in complex $\mathbf{1}$ is in a distorted square pyramidal environment, while in $\mathbf{2}$, the iron(III) center is six-coordinate with distorted octahedral geometry. The Schiff base ligands $\mathrm{L}^{1}$ and $\mathrm{L}^{2}$ occupied the basal sites, with chloride and water occupying the apical sites. Magnetic susceptibility and Mössbauer effect measurements showed a high-spin configuration $(S=5 / 2)$ for $\mathrm{Fe}(\mathrm{III})$ in $\mathbf{1}$ and $\mathbf{2}$. The temperature dependence of the magnetic data for complexes $\mathbf{1}$ and $\mathbf{2}$ is analyzed in terms of the spin-Hamiltonian formalism, which gives an accurate estimate of the zero-field splitting of the ground state of the iron(III) ions as $D=10.2 \mathrm{~cm}^{-1}\left(E=3.4 \mathrm{~cm}^{-1}\right)$ and $D=7.2 \mathrm{~cm}^{-1}\left(E=2.4 \mathrm{~cm}^{-1}, \mathrm{zJ}^{\prime}=-0.5\right.$ $\left.\mathrm{cm}^{-1}\right)$, respectively, in the above two complexes. It has been found for the first time that complexes $\mathbf{1}$ and $\mathbf{2}$ activate the epoxidation of cis-stilbene by $\mathrm{NaOCl}$. With 1, the epoxides were produced in 40\% yield with cis: trans $=20: 80$, and with 2 , the epoxides were produced in $90 \%$ yield with cis:trans $=40: 60$.
\end{abstract}

\section{Introduction}

Oxygen activation and transfer by cytochrome P-450 has attracted the attention of organic chemists in particular, since it catalyses the mono-oxygenation of various compounds, both biotic and exobiotic, with high stereo- and regioselectivity under mild conditions. The P-450-catalyzed oxygen transfer reaction was proposed by Groves and Nemo to proceed through an oxohaem catalytic intermediate. ${ }^{1,2}$ Furthermore, Groves and co-workers have reported that simple iron(III) porphyrins are good models for the reaction site of cytochrome P-450. ${ }^{2}$ From these basic results, many optically active iron(III) and manganese(III) porphyrins were synthesized and have been found to be efficient catalysts for the epoxidation of olefins. ${ }^{3-6}$

Parallel to these metal-porphyrin complexes, the use of manganese(III) complexes of substituted salen ligands [salen = $N, N$-(ethylene)bis(salicylideneaminate)] as a catalyst for the epoxidation of olefins has been widely investigated. ${ }^{7-11}$ An increase in the enantioselectivities for these substrates has been achieved by modulating the steric and electronic properties of the catalyst through varying the substitution pattern at the salicylidene moiety and the diamine fragment. ${ }^{9}$ Surprisingly, very little attention has been paid to studies on the epoxidation of olefins using salen-iron(III) complexes. Although several substituted iron(III)-salen complexes have been investigated as models for catechol dioxygenase, ${ }^{12}$ to our knowledge, no example of olefin epoxidation using iron(III)-salen catalysts has been reported.

Here, we report the preparation, crystal structures, magnetic properties, and the first catalytic activity in the epoxidation of cis-stilbene with $\mathrm{NaOCl}$ of mononuclear iron(III) complexes with substituted salen ligands (Scheme 1).

\section{Experimental}

\section{Materials}

The salicylaldehyde, 3-methoxysalicylaldehyde, 1,1'-dimethyl-

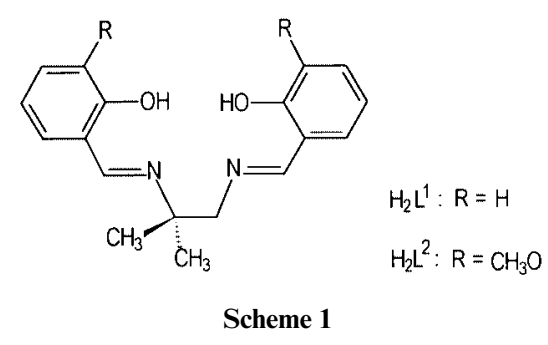

ethylenediamine, ferric chloride, cis-stilbene and cis- and transstilbene oxide used were all commercial samples from Aldrich. The sodium hypochlorite solution was from Riedel-de Haën.

\section{Syntheses of $\left[\mathrm{Fe}\left(\mathrm{L}^{1}\right) \mathrm{Cl}\right] \cdot \mathrm{CH}_{3} \mathrm{CN}(1)$ and $\left[\mathrm{Fe}\left(\mathrm{L}^{2}\right) \mathrm{Cl}\left(\mathrm{H}_{2} \mathrm{O}\right)\right] \cdot$} $1 / 3 \mathrm{CH}_{3} \mathrm{Cl}$ (2)

The Schiff bases $\mathrm{H}_{2} \mathrm{~L}^{1}$ and $\mathrm{H}_{2} \mathrm{~L}^{2}$ were obtained from the reaction of salicylaldehyde or 3-methoxysalicylaldehyde and 1,1'dimethylethylenediamine in methanol, respectively. The iron(III) complexes with $\mathrm{H}_{2} \mathrm{~L}^{1}$ and $\mathrm{H}_{2} \mathrm{~L}^{2}$ were obtained according to standard methods. A methanol solution containing anhydrous $\mathrm{FeCl}_{3}$ and the ligand was refluxed for $7 \mathrm{~h}$ in air and the desired powder iron(III) complexes $\mathbf{1}$ and $\mathbf{2}$ were filtered off. Single crystals of $\mathbf{1}$ and $\mathbf{2}$ were grown from acetonitrile and chloroform, respectively. Anal. found: C, 55.93; H, 4.98; N, 9.95. Calc. for $\mathrm{C}_{18} \mathrm{H}_{18} \mathrm{~N}_{3} \mathrm{O}_{2} \mathrm{FeCl} \cdot \mathrm{CH}_{3} \mathrm{CN}$ (1): C, 56.30; H, 4.96; N, 9.85\%. IR $(\mathrm{KBr}) v(\mathrm{CN}) / \mathrm{cm}^{-1}$ : 1611. Found: C, 48.03; H, 4.70; N, 5.32. Calc. for $\mathrm{C}_{20} \mathrm{H}_{24} \mathrm{~N}_{2} \mathrm{O}_{5} \mathrm{FeCl} \cdot 1 / 3 \mathrm{CHCl}_{3}(2)$ : C, 48.53; H, 4.81; N, $5.57 \%$. IR $(\mathrm{KBr}) v(\mathrm{CN}) / \mathrm{cm}^{-1}: 1607$.

\section{Crystallography}

Crystal data. Complex 1. $\mathrm{C}_{20} \mathrm{H}_{21} \mathrm{~N}_{3} \mathrm{O}_{2} \mathrm{FeCl}, \quad M=426.70$, orthorhombic, space group Pbca, $a=14.701$ (4), $b=13.552$ (4), $c=19.941(3) \AA$, crystal size $=0.20 \times 0.20 \times 0.20 \mathrm{~mm}, \quad V=$ $3972.7(16) \AA^{3}, D_{\mathrm{c}}(Z=8)=1.427 \mathrm{~g} \mathrm{~cm}^{-3}, \mu=9.008 \mathrm{~cm}^{-1}$, $2 \theta_{\text {max }}=50.0^{\circ}, N=3490, N_{\mathrm{o}}=1370, R=0.049, R^{\prime}=0.049$. 
Complex 2. $\mathrm{C}_{20.33} \mathrm{H}_{24.33} \mathrm{~N}_{2} \mathrm{O}_{5} \mathrm{FeCl}_{2}, \quad M=503.17$, trigonal, space group $R \overline{3}, a=25.189(7), c=18.061(6) \AA$, crystal size $=$ $0.25 \times 0.30 \times 0.40 \mathrm{~mm}, V=9924(4) \AA^{3}, D_{\mathrm{c}}(Z=18)=1.515 \mathrm{~g}$ $\mathrm{cm}^{-3}, \quad \mu=8.290 \mathrm{~cm}^{-1}, \quad 2 \theta_{\max }=50.0^{\circ}, \quad N=4284, \quad N_{\mathrm{o}}=1868$, $R=0.069, R^{\prime}=0.070$.

The X-ray crystal data were collected at $298 \mathrm{~K}$ using an Enraf-Nonius CAD4 diffractometer equipped with graphitemonochromated Mo-K $\alpha$ radiation $(\lambda=0.70930 \AA), 2 \theta$ scan mode. The $N$ independent reflections and $N_{\mathrm{o}}$ with $I>2.0 \sigma(I)$ were observed. The structures were solved by location of heavy atoms using a Patterson map and refined (based on $F$ ) by a full-matrix least-squares method using the NRCVAX software package. ${ }^{13}$

CCDC reference number 186/1822.

See http://www.rsc.org/suppdata/dt/a9/a908648j/ for crystallographic files in .cif format.

\section{Physical measurements}

The IR spectra were recorded on a Bio-Rad FTS40 FTIR spectrophotometer as $\mathrm{KBr}$ pellets in the $4000-400 \mathrm{~cm}^{-1}$ region and the X-band EPR spectra were recorded at $77 \mathrm{~K}$ for the complexes as powders on a Bruker ESC-106 spectrometer. The temperature dependence of the magnetic susceptibility of polycrystalline samples was measured between 4 and $300 \mathrm{~K}$ in a field of $1 \mathrm{~T}$ using a SQUID magnetometer. Diamagnetic corrections were made using Pascal's constants. ${ }^{14}$ The Mössbauer spectra of the powdered samples at $80 \mathrm{~K}$ were observed with an ASA 600 Mössbauer spectrometer, with a ${ }^{57} \mathrm{Co}(\mathrm{Rh})$ radiation source. Iron foil was used as a standard for isomer shifts.

\section{Reaction of $\mathrm{NaOCl}$ with cis-stilbene catalyzed by $\left[\mathrm{Fe}\left(\mathrm{L}^{1}\right) \mathrm{Cl}\right]$ $\mathrm{CH}_{3} \mathrm{CN}(1)$ and $\left[\mathrm{Fe}\left(\mathrm{L}^{2}\right) \mathrm{Cl}\left(\mathrm{H}_{2} \mathrm{O}\right)\right] \cdot 1 / 3 \mathrm{CHCl}_{3}(2)$}

An unbuffered, undiluted aqueous solution of commercial sodium hypochlorite $(13 \% \mathrm{w} / \mathrm{w}, 0.40 \mathrm{ml}, 0.56 \mathrm{mmol})$ was slowly added to a solution of cis-stilbene $(0.101 \mathrm{~g}, 0.56 \mathrm{mmol})$ in $\mathrm{CH}_{2} \mathrm{Cl}_{2}(10 \mathrm{ml})$ and complex $1(0.01 \mathrm{~g}, 0.03 \mathrm{mmol})$ or complex 2 dissolved in methylene chloride $(10 \mathrm{ml})$. After complete addition, the mixture was stirred for $10 \mathrm{~h}$ and the methylene chloride removed under reduced pressure. The organic products were extracted with diethyl ether, dried with $\mathrm{Na}_{2} \mathrm{SO}_{4}$ and filtered. Analysis by NMR spectroscopy, using 1,4-dibromobenzene in $\mathrm{CDCl}_{3}$ as an internal standard, showed the presence of cis-stilbene oxide (singlet, $\delta 4.25$ ) and a trans-stilbene oxide (singlet, $\delta 3.85$ ).

\section{Results and discussion}

\section{Crystal structures of complexes 1 and 2}

The X-ray crystal structures (without the solvent molecules) of complexes $\mathbf{1}$ and $\mathbf{2}$ are illustrated in Figs. 1 and 2, respectively. Selected bond distances and angles relevant to the iron coordination sphere are listed in Tables 1 and 2.

The coordination geometry around each iron atom can be described as a distorted square pyramid for $\mathbf{1}$ and an elongated distorted octahedron for $\mathbf{2}$. In compound $\mathbf{1}$ the equatorial sites are occupied by the $\mathrm{N}_{2} \mathrm{O}_{2}$ donor atoms of the ligand $\mathrm{L}^{1}$, with average bond distances of $\mathrm{Fe}-\mathrm{N}=1.971(5)$ and $\mathrm{Fe}-\mathrm{O}=1.868(5) \AA$, and the apical chloride atom, with $\mathrm{Fe}-\mathrm{Cl}=$ $2.4468(24) \AA$. In compound 2 , two apical sites are occupied by the chloride and the water oxygen atom, with $\mathrm{Fe}-\mathrm{Cl}=2.322(3)$ and $\mathrm{Fe}-\mathrm{O}(5)=2.209(6) \AA$, and the basal coordination plane consists of the $\mathrm{N}_{2} \mathrm{O}_{2}$ donor atoms of the $\mathrm{HL}^{2}$ ligand, with average bond distances of $\mathrm{Fe}-\mathrm{N}=2.074(6)$ and $\mathrm{Fe}-\mathrm{O}=$ $1.890(2) \AA$.

Since the space group of $\mathbf{1}$ has an inversion center, the 8 molecules have to be present as pairs with opposite chirality. The central $\mathrm{C}-\mathrm{N}-\mathrm{N}-\mathrm{C}$ chelate ring of the 1,1'-dimethylethylenediimine ligand in complexes $\mathbf{1}$ (Fig. 1) and $\mathbf{2}$ (Fig. 2) has to

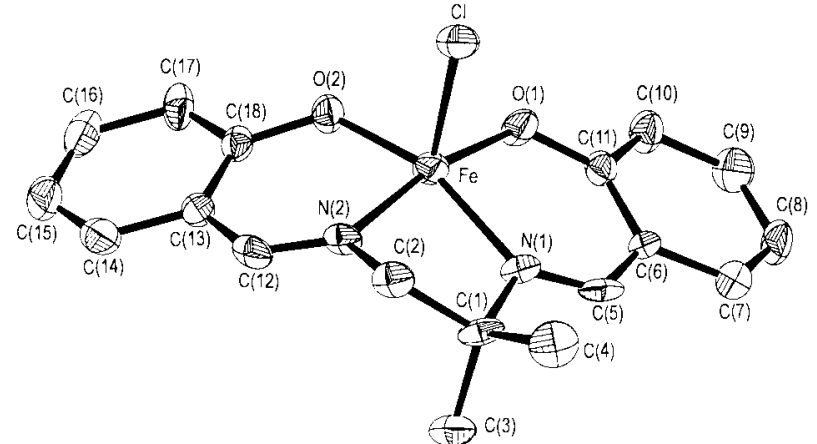

Fig. 1 Perspective view of complex 1 with the atom numbering scheme. The solvent $\mathrm{CH}_{3} \mathrm{CN}$ is omitted for clarity. Thermal ellipsoids are drawn at the $30 \%$ probability level.

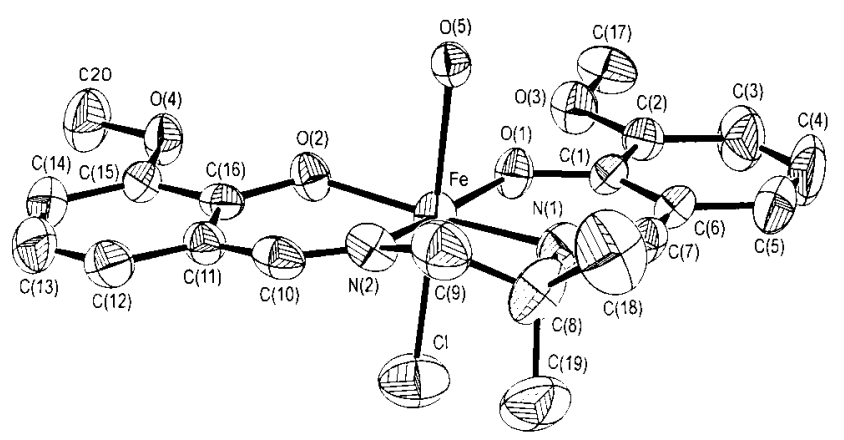

Fig. 2 Perspective view of complex 2 with the atom numbering scheme. The solvent $\mathrm{CHCl}_{3}$ is omitted for clarity. Thermal ellipsoids are drawn at the $30 \%$ probability level.

Table 1 Selected bond distances $(\AA)$ and angles $\left(^{\circ}\right)$ for $\left[\mathrm{Fe}\left(\mathrm{L}^{1}\right) \mathrm{Cl}\right]$. $\mathrm{CH}_{3} \mathrm{CN} 1$

\begin{tabular}{lllr}
\hline $\mathrm{Fe}-\mathrm{Cl}$ & $2.4468(24)$ & $\mathrm{Fe}-\mathrm{O}(1)$ & $1.869(5)$ \\
$\mathrm{Fe}-\mathrm{O}(2)$ & $1.866(5)$ & $\mathrm{Fe}-\mathrm{N}(1)$ & $1.990(6)$ \\
$\mathrm{Fe}-\mathrm{N}(2)$ & $1.953(5)$ & $\mathrm{C}(5)-\mathrm{N}(1)$ & $1.270(10)$ \\
$\mathrm{C}(11)-\mathrm{O}(4)$ & $1.318(8)$ & $\mathrm{C}(12)-\mathrm{N}(2)$ & $1.270(10)$ \\
$\mathrm{C}(18)-\mathrm{O}(2)$ & $1.317(9)$ & & \\
& & & \\
$\mathrm{Cl}-\mathrm{Fe}-\mathrm{O}(1)$ & $100.02(18)$ & $\mathrm{Cl}-\mathrm{Fe}-\mathrm{O}(2)$ & $100.49(17)$ \\
$\mathrm{Cl}-\mathrm{Fe}-\mathrm{N}(1)$ & $98.62(18)$ & $\mathrm{Cl}-\mathrm{Fe}-\mathrm{N}(2)$ & $91.79(18)$ \\
$\mathrm{O}(1)-\mathrm{Fe}-\mathrm{O}(2)$ & $92.32(22)$ & $\mathrm{O}(1)-\mathrm{Fe}-\mathrm{N}(1)$ & $92.29(22)$ \\
$\mathrm{N}(1)-\mathrm{Fe}-\mathrm{N}(2)$ & $80.65(24)$ & $\mathrm{N}(2)-\mathrm{Fe}-\mathrm{O}(2)$ & $90.68(23)$ \\
$\mathrm{O}(1)-\mathrm{Fe}-\mathrm{N}(2)$ & $167.06(23)$ & $\mathrm{O}(2)-\mathrm{Fe}-\mathrm{N}(1)$ & $159.23(24)$ \\
& & &
\end{tabular}

Table 2 Selected bond distances $(\AA)$ and angles $\left({ }^{\circ}\right)$ for $\left[\mathrm{Fe}\left(\mathrm{L}^{2}\right) \mathrm{Cl}\left(\mathrm{H}_{2} \mathrm{O}\right)\right]$. $1 / 3 \mathrm{CHCl}_{3} 2$

\begin{tabular}{lclr}
\hline $\mathrm{Fe}-\mathrm{Cl}$ & $2.322(3)$ & $\mathrm{Fe}-\mathrm{O}(5)$ & $2.209(6)$ \\
$\mathrm{Fe}-\mathrm{O}(1)$ & $1.888(5)$ & $\mathrm{Fe}-\mathrm{O}(2)$ & $1.892(5)$ \\
$\mathrm{Fe}-\mathrm{N}(1)$ & $2.082(6)$ & $\mathrm{Fe}-\mathrm{N}(2)$ & $2.066(6)$ \\
$\mathrm{C}(1)-\mathrm{O}(1)$ & $1.311(9)$ & $\mathrm{C}(16)-\mathrm{O}(2)$ & $1.331(9)$ \\
$\mathrm{C}(7)-\mathrm{N}(1)$ & $1.251(12)$ & $\mathrm{C}(10)-\mathrm{N}(2)$ & $1.283(11)$ \\
& & & \\
$\mathrm{Cl}-\mathrm{Fe}-\mathrm{O}(5)$ & $174.23(16)$ & $\mathrm{Cl}-\mathrm{Fe}-\mathrm{O}(1)$ & $98.18(19)$ \\
$\mathrm{Cl}-\mathrm{Fe}-\mathrm{O}(2)$ & $93.49(19)$ & $\mathrm{Cl}-\mathrm{Fe}-\mathrm{N}(1)$ & $93.63(21)$ \\
$\mathrm{Cl}-\mathrm{Fe}-\mathrm{N}(2)$ & $90.42(21)$ & $\mathrm{O}(5)-\mathrm{Fe}-\mathrm{O}(1)$ & $87.25(21)$ \\
$\mathrm{O}(5)-\mathrm{Fe}-\mathrm{O}(2)$ & $87.49(21)$ & $\mathrm{O}(5)-\mathrm{Fe}-\mathrm{N}(1)$ & $90.09(25)$ \\
$\mathrm{O}(1)-\mathrm{Fe}-\mathrm{O}(2)$ & $99.54(21)$ & $\mathrm{O}(2)-\mathrm{Fe}-\mathrm{N}(2)$ & $88.93(24)$ \\
$\mathrm{N}(1)-\mathrm{Fe}-\mathrm{N}(2)$ & $80.3(3)$ & $\mathrm{O}(1)-\mathrm{Fe}-\mathrm{N}(2)$ & $167.48(24)$ \\
$\mathrm{O}(2)-\mathrm{Fe}-\mathrm{N}(1)$ & $167.1(3)$ & & \\
\end{tabular}

be present in a $\lambda$ form and a $\delta$ form, respectively, and in Fig. 3 both chiralities of $\mathbf{2}$ are shown. The displacements of the Fe(III) ions from $\mathrm{O}(1), \mathrm{O}(2), \mathrm{N}(2)$, and $\mathrm{N}(1)$ equatorial planes of complexes 1 and 2 are 0.266 and $0.141 \AA$, respectively, these are smaller than that of $0.46 \AA$ observed for $\mathrm{Fe}\left(\right.$ salen) $\mathrm{Cl}^{15,16}$ The displacement of iron from the $\mathrm{N}_{2} \mathrm{O}_{2}$ plane reflects the strain exerted by the ligand structure. The smaller displacement of 


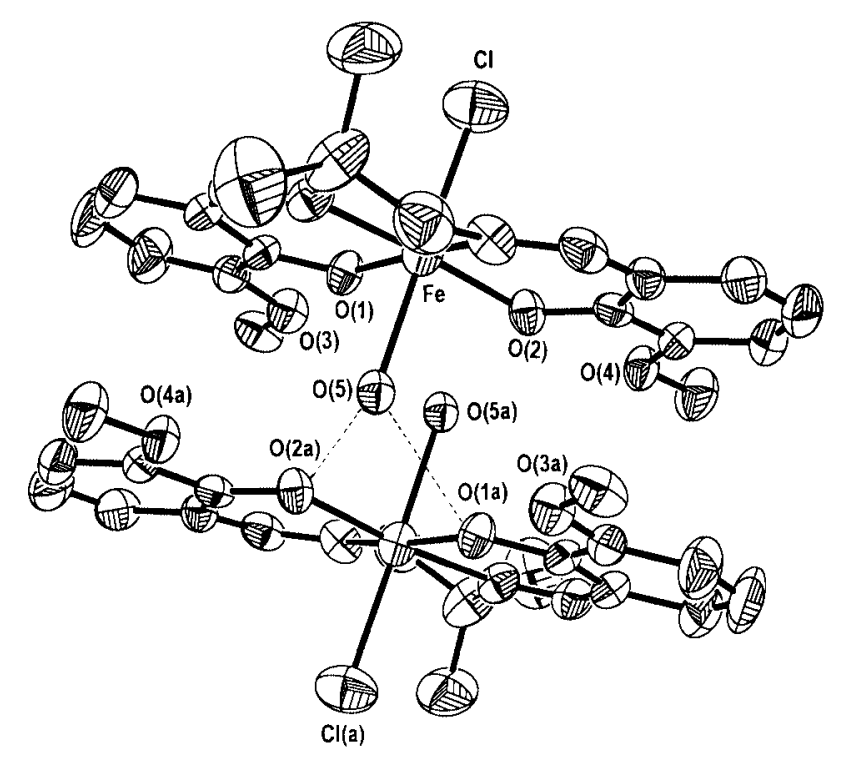

Fig. 3 View of the packing of the molecules in complex 2. Weak intermolecular hydrogen bonds are shown by dotted lines.

$\mathrm{Fe}(\mathrm{III})$ ion from the $\mathrm{N}_{2} \mathrm{O}_{2}$ plane in $\mathbf{2}$ may be due to the second apical ligand (water), which makes hydrogen bonds between the hydrogens of $\mathrm{H}_{2} \mathrm{O}$ and the oxygen atoms of the basal ligand. As shown in Fig. 3, the closest intermolecular interactions occur between the $\left[\mathrm{Fe}\left(\mathrm{L}^{2}\right) \mathrm{Cl}\left(\mathrm{H}_{2} \mathrm{O}\right)\right]$ molecules which are held together in pairs by hydrogen bonding in which $\mathrm{O}(5)$ makes hydrogenbonding contacts to atoms $\mathrm{O}(1 \mathrm{~A})$ and $\mathrm{O}(2 \mathrm{~A})$ at distances of 2.863(7) and 2.808(7) $\AA$, respectively. However, the two water molecules do not hydrogen-bond with each other $[\mathrm{O}(5) \cdots \mathrm{O}(5 \mathrm{a})=3.560(9) \AA]$. Studies of iron(III)-salen systems have shown that the metal-to-imine nitrogen bond distance is sensitive to the electronic spin state of the metal ion. ${ }^{17,18}$ In iron(III) complexes, the metal-to-imine nitrogen distances are in the range $2.00-2.10 \AA$ for the high-spin state and in the range $1.93-1.96 \AA$ for the low-spin case. In the structures of complexes $\mathbf{1}$ and $\mathbf{2}$ reported here, the mean $\mathrm{Fe}-\mathrm{N}$ bond distances of 1.971(5) $\AA$ for $\mathbf{1}$ and 2.074(6) $\AA$ for 2, respectively, suggest that the metal ion in $\mathbf{1}$ and $\mathbf{2}$ is in the high-spin state, which is consistent with the results of room temperature magnetic susceptibility and Mössbauer effect measurements (see below).

\section{EPR and Mössbauer spectra}

The powder X-band EPR spectra at $77 \mathrm{~K}$ of both complexes show a weak absorption signal near $g=4.50$ and strong broad lines at $g \approx 2.0$ with line widths of $0.08-0.20 \mathrm{~T}$. The width of the individual absorption lines making up the pattern for complex 2 is estimated at $0.20 \mathrm{~T}$ and is attributed primarily to intermolecular interactions. The line near $g=4.50$, observed in the spectra of $\mathbf{1}$ and $\mathbf{2}$, is generally associated with rhombically distorted high-spin Fe(III) complexes and is predicted to occur as the ratio of the zero-field splitting (ZFS) parameters $E: D$ approaches $1: 3$ the rhombic limit. ${ }^{19}$

Mössbauer spectra at $80 \mathrm{~K}$ for powdered samples of $\mathbf{1}$ and 2 consist of single asymmetric quadrupole-split doublets. A representative spectrum of $\mathbf{2}$ is shown in Fig. 4. The values of the isomer shift (IS) and quadrupole splitting (QS), obtained by computer fitting two unconstrained Lorentzian lines to the spectra, are: IS $(\mathrm{QS})=0.52 \mathrm{~mm} \mathrm{~s}^{-1}\left(0.96 \mathrm{~mm} \mathrm{~s}^{-1}\right)$ for $\mathbf{1}$ and $0.56 \mathrm{~mm} \mathrm{~s}^{-1}\left(0.90 \mathrm{~mm} \mathrm{~s}^{-1}\right)$ for 2 . These parameters lie in the range expected for typical high-spin $(S=5 / 2)$ square-pyramidal $\mathrm{FeN}_{4} \mathrm{O}_{2}$ Schiff-base systems. ${ }^{19,20}$ It is interesting to note that the QS value of $\mathbf{1}$ is larger than that of $\mathbf{2}$. The rather larger displacement of the iron atom from the basal plane in complex 1 would be expected to increase the ligand field distortion and lead to a larger QS value.

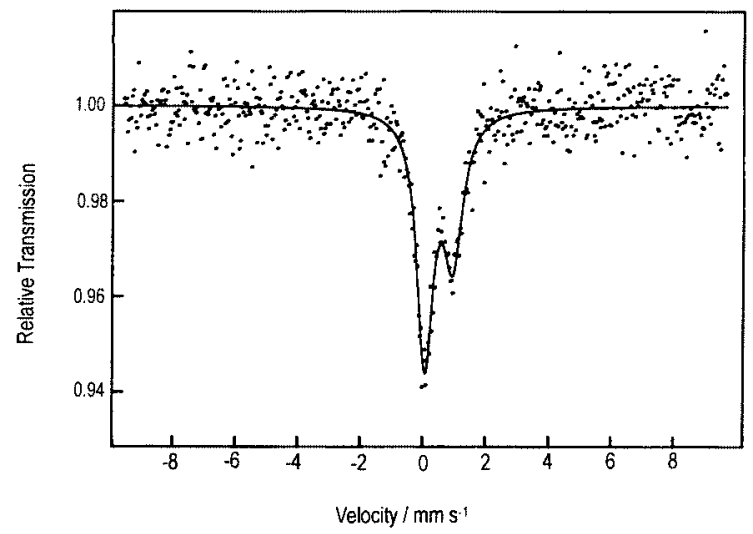

Fig. 4 Mössbauer spectra at $80 \mathrm{~K}$ for complex 2 . The solid line was plotted using the fitting parameters reported in the text.

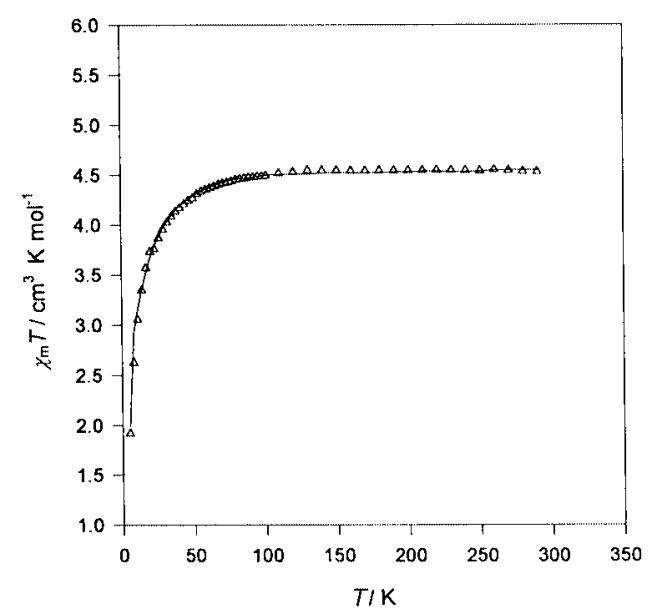

Fig. 5 Temperature dependence of $\chi_{\mathrm{m}} T$ for complex 2 . The solid line was calculated with the fitting parameters reported in the text.

\section{Magnetic properties}

The temperature dependence of $\chi_{\mathrm{m}} T$ for complexes $\mathbf{1}$ and $\mathbf{2}$ shows a similar pattern and the entire characteristic expected for a monomeric $\mathrm{Fe}(\mathrm{III})$ complex with a rather large zero-field splitting of the ${ }^{6} \mathrm{~A}_{1}$ state. ${ }^{20,21}$ A representative plot of $\chi_{\mathrm{m}} T$ vs. $T$ for 2 is illustrated in Fig. 5. Above $c a .65 \mathrm{~K}$ the $\chi_{\mathrm{m}} T$ value is 4.52 $\mathrm{cm}^{3} \mathrm{~K} \mathrm{~mol}^{-1}$ and is independent of temperature. Below $65 \mathrm{~K}$ it begins to decrease quite rapidly, with a marked curvature in the plot, reaching a value of $1.92 \mathrm{~cm}^{3} \mathrm{~K} \mathrm{~mol}^{-1}$ at $4 \mathrm{~K}$. This behavior is generally reminiscent of a ${ }^{6} \mathrm{~A}_{1}$ state, having considered zero-field splitting and weak intermolecular magnetic interactions. ${ }^{19-21}$

The observed susceptibilities were analyzed with the rhombic spin Hamiltonian ${ }^{19-21}$ and it was assumed that $E: D$ approached the rhombic limit of $1: 3$.

$$
H=g \mu_{\mathrm{B}} H S_{i z}+D\left[S_{i z}{ }^{2}-(1 / 3) S(S+1)\right]+E\left(S_{i x}{ }^{2}-S_{i y}{ }^{2}\right)
$$

The data cannot be well-described solely by eqn. 1; a molecular field correction must be applied to eqn. 1 to account for the presence of additional intermolecular exchange:

$$
\chi_{\mathrm{m}}=\chi\left[1-\left(2 z J^{\prime} / N g^{2} \mu_{\mathrm{B}}^{2}\right) \chi\right]
$$

where $J^{\prime}$ is the intermolecular interaction parameter, and $z$ is the number of nearest neighbors around a given magnetic molecule in the crystal lattice.

Careful and systematic variation of $D, E$, and $z J^{\prime}$ showed that acceptable fits could be obtained for the following parameter values: $D=10.2\left(E=3.4, z J^{\prime}=0 \mathrm{~cm}^{-1}, g=2.0\right)$ for 1 and $D=7.2\left(E=2.4, J^{\prime}=0.5 \mathrm{~cm}^{-1}, z=1, g=2.0\right)$ for 2 . The 
weak intermolecular antiferromagnetic exchange $\left(J^{\prime}\right)$ observed in 2 presumably originates through the pairwise interactions described above and is shown in Fig. 4. If a superexchange pathway via $\mathrm{H}$-bonded fragments of the type $\mathrm{Fe}-\mathrm{OH}_{2}$ $\mathrm{O}$ (salen)-Fe is involved, then $J^{\prime}$ would be expected to be small, as is observed.

\section{Epoxidation}

Sodium hypochlorite was found to react readily with substituted derivatives of the salen-Fe(III) complexes $\mathbf{1}$ and $\mathbf{2}$ in the presence of cis-stilbene to produce trans- and cis-epoxides in good yield. With 1, epoxides were produced in $40 \%$ yield with cis: trans $=20: 80$, and with 2, epoxides were produced in $90 \%$ yield with cis:trans $=40: 60$. These data clearly show that the cis-stilbene produced higher yields of trans-epoxide, the product mixtures containing 20 and $40 \%$ of the corresponding cis isomer, and the relative reactivity of epoxidation was sensitive to the substitution on the Schiff-base ligands. It has been observed that $c i s$-stilbene reacts with iron-porphyrin complexes to give high yields of cis-stilbene epoxide containing a minor amount of the corresponding trans isomer. ${ }^{1-5}$ Therefore, it is somewhat surprising that the epoxidation of cis-stilbene with $\mathrm{NaOCl}$ catalyzed by complexes $\mathbf{1}$ and $\mathbf{2}$ gave high yields of trans-stilbene epoxide, similarly to the epoxidation of cis-olefins catalyzed by $\mathrm{Mn}$ (salen) derivatives, which essentially favors the production of trans-epoxide products. ${ }^{7-9}$ At this stage, no clear mechanism accounts for the selective formation of transepoxides from cis-olefins by using complexes $\mathbf{1}$ and $\mathbf{2}$. We propose at this moment that the mechanism for the $\mathrm{Mn}$ (salen)catalyzed cis-stilbene epoxidation ${ }^{8 c, 22-24}$ including a radical intermediate with rotational collapse could explain the present results. More detailed studies on the mechanism and enantioselectivity for the present $\mathrm{Fe}$ (salen)-catalyzed epoxidation are currently being made in this laboratory.

In summary, the results indicate that under the same conditions, epoxidation of $c i s$-stilbene with $\mathrm{NaOCl}$ catalyzed by complex 1 provided $80 \%$ selectivity for trans-stilbene oxide but only $40 \%$ conversion, while when catalyzed by complex 2 , the conversion of epoxidation of cis-stilbene rose to $90 \%$. The higher conversion and trans-stilbene oxide formation with complex 2 could be due either to steric or electronic effects of the $\mathrm{OCH}_{3}$ group in positions $\mathrm{C}(2)$ and $\mathrm{C}(15)$ of the phenoxide moiety of the $\mathrm{L}^{2}$ ligand. It has been observed by $\mathrm{Kochi}^{7}$ and Jacobsen and co-workers ${ }^{8 a, 23,24}$ that (salen)manganese(III) complexes with bulky groups at $\mathrm{C}(3)$ and $\mathrm{C}\left(3^{\prime}\right)$ of the salen moiety make excellent catalysts for the epoxidation of cis-olefins. These results indicated that the yield and the stereo-selectivity of the metal-salen-complex-catalyzed olefin-epoxidation is strongly dependent on the steric ${ }^{9 b, 24}$ and electronic ${ }^{25}$ effects of the substituents on the salen moiety.

\section{Acknowledgements}

The authors thank the National Science Council of Taiwan for financial support via a grant (NSC-89-2113-M-032-009).

\section{References}

1 R. E. White and M. J. Coon, Annu. Rev. Biochem., 1980, 49, 315

2 J. T. Groves, T. E. Nemo and R. S. Myers, J. Am. Chem. Soc., 1979, 101, 1032; J. T. Groves and T. E. Nemo, J. Am. Chem. Soc., 1983, 105, 5786; J. T. Groves, R. C. Haushalter, M. Nakamura, T. E. Nemo and B. J. Evans, J. Am. Chem. Soc., 1981, 103, 2884; J. T. Groves and Y. Watanabe, J. Am. Chem. Soc., 1988, 110, 8443.

3 J. T. Groves and R. S. Myers, J. Am. Chem. Soc., 1983, 105, 5791; J. T. Groves and P. Viski, J. Org. Chem., 1990, 55, 3628.

4 S. O'Malley and T. Kodadek, J. Am. Chem. Soc., 1989, 111, 9116.

5 Y. Naruta, F. Tani, N. Ishihara and K. Maruyama, J. Am. Chem. Soc., 1991, 113, 6865

6 S. J. Yang and W. Nam, Inorg. Chem., 1998, 37, 606.

7 K. Srinivasan, P. Michaud and J. K. Kochi, J. Am. Chem. Soc., 1986, 108, 2309.

8 (a) W. Zhang, J. L. Loebach, S. R. Wilson and E. N. Jacobsen, J. Am. Chem. Soc., 1990, 112, 2801; (b) E. N. Jacobsen, in Catalytic Asymmetric Synthesis, ed. I. Ojima, VCH, New York, 1993, pp. 386436; (c) S. Chang, J. M. Galvin and E. N. Jacobsen, J. Am. Chem. Soc., 1994, 116, 6937; (d) N. S. Finney, P. J. Pospisil, S. Chang, M. Palucki, R. G. Konsler, K. B. Hansen and E. N. Jacobsen, Angew. Chem., Int. Ed. Engl., 1997, 36, 1720; (e) M. Tokunaga, J. F. Larrow, F. Kakiuchi and E. N. Jacobsen, Science, 1997, 277, 936; ( $f$ ) A. Waldemar, T. F. Rainer, R. S. Veit and R. S.-M. Chantu, J. Am. Chem. Soc., 1998, 120, 708; $(g)$ M. S. Sigman and E. N. Jacobsen, J. Am. Chem. Soc., 1998, 120, 403.

9 (a) T. Katsuki, Coord. Chem. Rev., 1995, 140, 189; (b) T. Linker, Angew. Chem., Int. Ed. Engl., 1997, 36, 2060; (c) Y. N. Ito and T. Katsuki, Tetrahedron Lett., 1998, 39, 4325; (d) Y. N. Ito and T. Katsuki, Bull. Chem. Soc. Jpn., 1999, 72, 603; (e) L. Canali and D. C. Sherrington, Chem. Soc. Rev., 1999, 28, 85.

10 P. O. Norrby, J. Am. Chem. Soc., 1995, 117, 11035.

11 K. Bernardo, S. Leopard, A. Robert, G. Commenges, F. Dahan and B. Meunier, Inorg. Chem., 1996, 35, 387.

12 R. H. Heistand II, A. L. Roe and L. Que, Jr., Inorg. Chem., 1982, 21, 676; R. H. Heistand II, R. B. Lauffer, E. Fikrig and L. Que., Jr., J. Am. Chem. Soc., 1982, 104, 2789; J. W. Pyrz, A. L. Roe, L. J. Stern and L. Que, Jr., J. Am. Chem. Soc., 1985, 107, 614; L. Que, Jr., R. B. Lauffer, J. B. Lynch, B. P. Murch and J. W. Pyrz, J. Am. Chem. Soc., 1987, 109, 5381.

13 E. J. Gabe, Y. Le Page, J. P. Charland, F. L. Lee and P. S. White, J. Appl. Crystallogr., 1989, 22, 385.

14 O. Kahn, Molecular Magnetism, VCH, Weinheim, 1993, p. 3.

15 M. Gerloch and F. E. Mabbs, J. Chem. Soc. A, 1967, 1598.

16 H. Preut, R. Ruther and F. Huber, Acta Crystallogr., Sect. C, 1986, 42, 1154.

17 M. Calligaris, G. Nardin and L. Randaccio, Coord. Chem. Rev., 1972, 7, 385; N. J. Hairs and J. K. Beattie, Inorg. Chem., 1977, 16, 245.

18 W. T. Oosterhuis, Struct. Bonding (Berlin), 1974, 20, 59

19 B. Kennedy, G. Brain, E. Horn, K. S. Murray and M. R. Snow, Inorg. Chem., 1985, 24, 1647; B. J. Kennedy, A. C. McGrath, K. S. Murray, B. W. Skelton and A. H. White, Inorg. Chem., 1987, 26, 483.

20 K. J. Berry, P. E. Clark, K. S. Murray, C. L. Ralston and A. H. White, Inorg. Chem., 1983, 22, 3928.

21 V. R. Marathe and S. Mitra, J. Chem. Phys., 1983, 78, 915.

22 J. T. Groves and M. K. Stern, J. Am. Chem. Soc., 1987, 109, 3812.

23 W. Zhang, N. H. Lee and E. N. Jacobsen, J. Am. Chem. Soc., 1994, 116, 425.

24 E. N. Jacobsen, W. Zhang, L. C. Muci, J. R. Ecker and L. Deng, J. Am. Chem. Soc., 1991, 113, 7063.

25 E. N. Jacobsen, W. Zhang and M. L. Guller, J. Am. Chem. Soc., 1991, 113, 6703 .

Paper $a 908648 j$ 